\title{
COUNSELLING AGAINST EARLY MARRIAGE OF THE GIRL-CHILD IN ANAMBRA STATE
}

\author{
NWOKOLO, Chinyelu PhD \\ Department of Guidance and Counselling \\ Nnamdi Azikiwe University, \\ Awka \\ email: chinwokolo05@yahoo.com
}

\begin{abstract}
This study investigated the capacity building strategies for counselling against early marriage of the Girl-child in Ogidi Education zone of Anambra state. Three research questions were used and descriptive survey design was adopted. The population for the study is all the parents who are members of the parents' teachers' association of all the schools in Ogidi education zone and all the eleven counsellors in the chosen zone. A sample of 660 respondents was chosen through random sampling and all the 11 counsellors were chosen because the population size is small. On the whole 671 respondents were used for the study. Instrument used was questionnaire and mean rating was used as the statistical tool. The results showed that all but one of the items are the capacity building strategies as agreed by the respondents. This implies that unless the parents work together with the counsellors, counselling might not contribute much in the fight against early marriage of the Girl-child. Recommendations include that parents in conjunction with the counsellors should mount campaigns through seminars, workshops, etc to modify the girls' attitude towards early marriage.
\end{abstract}

\section{Introduction}

In every environment and culture there are some basic norms and beliefs that guide the people of the area. In Nigeria for instance, the people of Ogidi Education Zone of Anambra State still engage in early marriage of the Girl-child. This is because; they believe that early marriage decreases promiscuity of the girl-child (Anagbogu, 2005). Due to the ignorant and selfish nature of these people, they forget the devastating effect it has on the girl-child as well as their community development. More so the girlchild has no power to resist the offer. It then becomes necessary to proffer some capacity building strategies to help the girl-child withstand this abuse called early marriage. Early marriage according to Ango (1991) is either marriage of an adolescent girl/boy or marriage of an adolescent girl to a matured man or vice-versa and this happens at puberty when the 
individual is getting matured. The marital age according to Molokwu (2000) is above the age of 18 years, when the individual is physically, socially, academically and emotionally matured to cope with the challenges of marriage. The Nigerian review draft decree put the marriageable age of the girl-child at 18 years. Also the UNICEF (2001) on the rights of the child recommends that children should not be separated from their parents before 18 years unless it is considered necessary. Despite the above recommendations, the girl-child marriage is prevalent in Ogidi education zone of Anambra State. Reasons identified by Oyedepo (2001) on why girls engage in early marriage are poverty, unwanted pregnancy, parental pressure, peer pressure and developmental stage among others. Commenting on the above, Musaazi (2002) asserted that these young girls have no values of their own. They are only carried away by ignorance and sometimes parents.

This menace is against the UNICEF recommendations on the rights of the child and demands the adoption of capacity building strategies to stop these early marriages otherwise known as the Girl-child marriage. Moreso the effect of this negative trend is evident in emotional and mental distress, infidelity, intolerance, school drop-out, vesico vaginal fistula disease, early widowhood, not willing to be corrected, being extravagant with money, frustration and hatred for the man as observed by (Bala, 2003). However Orikpe and Amadi(2001) and Anagbogu(2005) advocated the need to adopt counselling strategies that will appeal to the conscience of the girl-child in shunning this early marriage.

Pre-marital counselling is one of the services provided by the counselling profession to help prepare the girl-child for marriage. It is the counsellor's role to help build capacities to ascertain that the girl-child imbibes intrinsic beliefs about the importance of maturity in marriage. To do this effectively, the girl-child needs a pool of capacity building strategies to draw from. Therefore the purpose of this study is to determine the pre-marital counselling strategies for curbing this menace.

The study is guided by three research questions.

1. What are the causes of early marriage of the Girl-child?

2. What are the consequences of early marriage of the Girl-child?

3. Through what capacity building strategies could the Girl-child be empowered to shun early marriage?

\section{Methodology}

This study is a survey research design. This design is ideal for this study because the study involved collecting and describing data obtained from 
a sample of population (Akuezilo \& Agu 2003). The study was carried out in Ogidi Education zone of Anambra state. This zone comprises six local government areas namely Anambra East, Anambra West, Idemili North, Idemili South, Oyi and Ayamelum local government areas. The population of the study is made up of all the eleven practicing counsellors in the zone and all the parents of the girl-child who are in Government secondary schools in Ogidi Education zone. These groups were used for the study because they hold key positions in influencing the girl-child. Data obtained from post- primary schools service commission (PPSSC) in 2008 reveals that there are 28 girls- schools, 5 mixed schools (boys and girls) and 11 counsellors in the zone. Simple random sampling technique was used to select 10 male- parents and 10 female- parents from each of the schools' Parents Teachers Association (PTA). On the whole 330 male- parents, 330 female- parents and 11 counsellors were used. The total sample for the study is 671 respondents.

The instrument used in this study was a researcher made questionnaire titled, counselling against early marriage (CAEM). It was a structured type of questionnaire containing sections A and B. Section A contain demographic information while section B contains 31 items. The items of the questionnaire were derived from reviewed literature and discussions with parents and counsellors. The responses to the questionnaire were designed on a 4- point scale of measurement of strongly agree, agree, disagree and strongly disagree. CAEM was face validated by two experts in guidance and counselling and one expert in measurement and evaluation all from Nnamdi Azikiwe University, Awka. They were given copies of the draft instrument, purpose of the study and research questions for content validation. CAEM was also subjected to a reliability test using- retest method of reliability. 10 male parents, 10 female parents and 3 counsellors from Oshimili south local Government of Delta state were used for the reliability. At the end of the second test, person product moment correlation analysis was employed and the coefficient alpha for sections B was 0.75 which indicates agreement between the two test results. The researcher used direct contact approach in collecting the data from the parents and counsellors. She also employed the services of two research assistants to facilitate the work. The data collected were analyzed using statistical tools. Reponses for the research questions wee answered using mean ratings. Any item with the mean of 2.50 and above was accepted as agreement with the statement. 


\section{Results}

The data collected were tallied and analyzed. They were built in tables to highlight the major findings. The results were then presented in sequential manner.

Table 1: Respondents' mean rating of the causes of early marriage.

\begin{tabular}{|l|l|c|c|c|}
\hline S/N & \multicolumn{1}{|c|}{ Items } & $\begin{array}{c}\mathbf{X} \\
\text { Cllor }\end{array}$ & $\begin{array}{c}\mathbf{X} \\
\mathrm{Mp}\end{array}$ & $\begin{array}{c}\mathbf{X} \\
\mathrm{Fp}\end{array}$ \\
\hline 1 & $\begin{array}{l}\text { Family pressure - from father, mother, sibling } \\
\text { and other relatives }\end{array}$ & 2.80 & 2.90 & 3.20 \\
\hline 2 & $\begin{array}{l}\text { Poverty-lack of finance in the girl's family and } \\
\text { harsh economic situation. }\end{array}$ & 3.10 & 3.40 & 3.15 \\
\hline 3 & $\begin{array}{l}\text { Unwanted Pregnancy - by the family and the } \\
\text { girl-child }\end{array}$ & 3.10 & 2.65 & 2.80 \\
\hline 4 & $\begin{array}{l}\text { Conspiracy - parents force a man on their girl- } \\
\text { child who had no choice but to adhere }\end{array}$ & 2.60 & 2.75 & 3.00 \\
\hline 5 & $\begin{array}{l}\text { Broken homes- where the girl-child is left at the } \\
\text { mercy of one parent }\end{array}$ & 2.60 & 2.70 & 3.10 \\
\hline 6 & $\begin{array}{l}\text { Peer pressure- Trying to belong ie marrying } \\
\text { because friends and age- mates are getting } \\
\text { married. }\end{array}$ & 3.1 & 3.3 & 3.5 \\
\hline 7 & $\begin{array}{l}\text { Virginity syndrome - because of cultural } \\
\text { attachment to virginity, the girls marry quickly } \\
\text { to maintain it. }\end{array}$ & 2.30 & 2.40 & 2.15 \\
\hline 8 & $\begin{array}{l}\text { Unhappy home- where there is persistent } \\
\text { discord in the girl's family. }\end{array}$ & 2.90 & 3.20 & 3.00 \\
\hline 9 & $\begin{array}{l}\text { Misconceptions - if you don't marry early, your } \\
\text { beauty will fade. }\end{array}$ & 2.40 & 2.30 & 2.25 \\
\hline 10 & $\begin{array}{l}\text { Culture - That is the way community do their } \\
\text { own things }\end{array}$ & 2.80 & 3.25 & 3.00 \\
\hline 11 & $\begin{array}{l}\text { Ignorance - lack of knowledge on the part of } \\
\text { the parents and their girl - child }\end{array}$ & 3.10 & 3.30 & 2.95 \\
\hline
\end{tabular}

Key: cllor - counsellor, $\mathrm{mp}$ - male parents, $\mathrm{fp}$ - female parents.

In Table 1, items 7 and 9 obtained mean rating below 2.50 in all the columns. The remaining items had mean ratings above 2.50 in the three columns. The conclusion is that the rest of the items are the causes of early marriage. 
Table 2. Respondents' mean ratings of consequences of early marriage.

\begin{tabular}{|l|l|c|c|c|}
\hline S/N & \multicolumn{1}{|c|}{ Items } & $\begin{array}{c}\mathbf{X} \\
\text { Cllor }\end{array}$ & $\begin{array}{c}\mathbf{X} \\
\mathrm{Mp}\end{array}$ & $\begin{array}{c}\mathbf{X} \\
\mathrm{Fp}\end{array}$ \\
\hline 1. & Vesico vaginal fistula disease & 3.45 & 2.95 & 3.10 \\
\hline 2. & $\begin{array}{l}\text { Early widowhood - where the girl - child marries } \\
\text { an old man who dies sooner or later }\end{array}$ & 2.70 & 2.60 & 2.75 \\
\hline 3. & $\begin{array}{l}\text { School - drop out - the girl is unable to continue } \\
\text { her education due to marriage. }\end{array}$ & 3.60 & 3.42 & 3.55 \\
\hline 4. & $\begin{array}{l}\text { The girls hates the man as soon as she discovers } \\
\text { that she made wrong choice }\end{array}$ & 3.00 & 2.90 & 3.20 \\
\hline 5. & The girl looks for sex outside the matrimonial & 2.94 & 3.15 & 3.05 \\
\hline 6. & Divorce due to immaturity & 2.90 & 2.85 & 2.74 \\
\hline 7. & Chances of fibroid because of early childbirth & 3.00 & 2.60 & 3.20 \\
\hline 8. & Intolerance due to difference in age & 3.01 & 3.30 & 3.41 \\
\hline 9. & Frustration sets in & 2.80 & 2.25 & 3.15 \\
\hline
\end{tabular}

Key: Cllor - counsellor, mp- male- parents, fp_f female-parents.

In Table 2 above the respondents rated all the items above 2.50. This indicates that they agree that vesico vaginal fistula disease, school drop-out, hatred for the man, sex outside marriage, early widowhood, frustration, intolerance and divorce are all consequences of Girl - child marriage.

Table -3 Respondents' mean rating on capacity building strategies.

\begin{tabular}{|l|l|c|c|c|}
\hline S/N & \multicolumn{1}{|c|}{ ITEM } & $\mathbf{X}$ & $\mathbf{X}$ & $\mathbf{X}$ \\
\cline { 3 - 5 } & cllor & $\mathrm{mp}$ & $\mathrm{fp}$ \\
\hline 1. & $\begin{array}{l}\text { Developing warm relations with the girl - child to } \\
\text { help her discuss her problems which may be } \\
\text { educational, vocational or social/person }\end{array}$ & 3.00 & 2.55 & 2.80 \\
\hline 2. & $\begin{array}{l}\text { Seminars, workshops and symposium should be } \\
\text { organized to explain to the girl - child the } \\
\text { consequences of early marriage }\end{array}$ & 3.18 & 2.76 & 2.12 \\
\hline 3. & $\begin{array}{l}\text { Parents should be more involved in the Girl - child } \\
\text { behaviour in school and at home }\end{array}$ & 3.54 & 3.16 & 3.41 \\
\hline 4. & $\begin{array}{l}\text { Counsellors should use child - friendly strategies } \\
\text { to encourage the Girl - child to study property }\end{array}$ & 3.60 & 3.63 & 3.17 \\
\hline 5. & $\begin{array}{l}\text { Counsellors should tell the girl that future is in her } \\
\text { hand so that she should focus more on education } \\
\text { in order to reach her optimal height }\end{array}$ & 3.08 & 3.44 & 3.47 \\
\hline
\end{tabular}




\begin{tabular}{|l|l|c|c|c|}
\hline S/N & \multicolumn{1}{|c|}{ ITEM } & X & X & X \\
\cline { 3 - 5 } & cllor & $\mathrm{mp}$ & $\mathrm{fp}$ \\
\hline 6. & $\begin{array}{l}\text { Counsellors should encourage the Girl - child with } \\
\text { learning difficulty by teaching her the tenants of } \\
\text { proper study habit }\end{array}$ & 3.18 & 2.81 & 2.88 \\
\hline 7. & $\begin{array}{l}\text { Parent and counsellors should educate the girl - } \\
\text { child on the appropriate time to get married }\end{array}$ & 2.17 & 3.40 & 2.40 \\
\hline 8. & $\begin{array}{l}\text { Parent Should use their own experience or } \\
\text { experience of others to let the girl child know the } \\
\text { intricacies of marriage in general and early } \\
\text { marriage in particular }\end{array}$ & 3.00 & 3.50 & 3.60 \\
\hline 9. & $\begin{array}{l}\text { Parents and counsellors should show affection and } \\
\text { heart felt concern to the girl - child to enable her } \\
\text { open up and share all her problems including } \\
\text { emotional problems }\end{array}$ & 3.40 & 3.60 & 3.45 \\
\hline 10. & $\begin{array}{l}\text { Parent and counsellors should show educate the } \\
\text { girl - child on the equal opportunity in life with } \\
\text { the boy - child }\end{array}$ & 3.60 & 3.00 & 3.20 \\
\hline 11. & $\begin{array}{l}\text { Pre-marital counselling should be included in the } \\
\text { school time table }\end{array}$ & 3.60 & 3.10 & 3.41 \\
\hline
\end{tabular}

Key; cllors - counsellors, mp-male-parents, fp-female-parent

In Table 3 all the respondents rated item 29 below 2.50, but the remaining items had mean ratings above 2.50 in the three columns. This indicates that the items are among the capacity building strategies that could be used to empower the girl - child.

\section{Discussion}

The result as presented in Table 1 showed that in the respondents' opinion family pressure, poverty, unwanted pregnancy, conspiracy, broken home, peer - pressure, unhappy home, culture and ignorance are all motives behind early marriage. This supports the assertions of UNICEF (2001) and the finding of Oyedepo (2001) and Musaazi (2002). This could be as a result of the cultural training girls receive which emphasized those that will help her as a house wife and a mother these cultural training suppresses her vocational and educational ambitions and pay attention to household duties. In Table 2 the respondents rated all the items as consequence of early marriage of the girl - child. This indicates that they agree that vesico -virginals fistula disease, early widowhood, school - drop out, hatred for the man sex outside marriage, frustration amongst others are the consequence of early marriage which 
is in line with Ango (1991) and Bala (2003) who highlighted the consequences in their own study earlier.

Finally the result presented in Table 3 showed that the respondents rated pre- marital counselling, educating the girl-child on the equal opportunity she has with the boy - child in all things including educational and social attainments, parents and counsellors showing affection to the girl-child to enable her share her problems in all areas of life, parents and counsellors using their personal experienced to counsel the girl-child, helping the girl-child understand the intricacies in early marriage, counselling the girl-child on proper study habit, counsellor organizing seminars, workshops and symposium to educate the girl-child on the disadvantages of early marriage, letting the girl-child know that her bright future is in her hand amongst other are all capacity building strategies for empowering the girl-child against early marriage. This finding confirms the advocacy of Anagbogu (2005), Orikpe\& Amadi (2001) and Molokwu (2000) who suggested the need to adopt counselling strategies that will appeal to the conscience of the girl-child to shun this menace. This is because the counsellors had acquired the necessary skills and techniques for capacity building earlier in their years of training. This implies that marriage counsellors should undertake pre-marital counselling of the girl-child by formal and non-formal Education.

\section{Recommendations}

1. The pre-marital counsellor, in conjunction with the community, should organize seminars and workshops where the girl-child will be sensitized on the need to shun early marriage.

2. The capacity building strategies identified in this study should be explored by the pre-marital counsellors.

3. Anambra women educationists should liaise with the practicing counsellors in schools to publish a handbook on early strategies needed to shun girl-child marriage.

4. The law-makers in Anambra State should pass a bill prohibiting early marriage.

5. Government should make education free and compulsory at the primary and secondary level to discourage early marriage.

6. Education planners should include sex education in the school curriculum for proper orientation of the girl-child.

\section{Conclusion}

Counselling against early marriage of the Girl- child is very necessary if our nascent democracy would move forward. This is because early 
marriage of the girl-child creates gender imbalance in the educational, economic, social and political sector of the nation amongst others.

Finally if the capacity building strategies are imbibed by the girls, then early marriage found amongst girls in Ogidi education zone of Anambra State will be drastically reduced.

\section{References}

Akuezuilo, E. O. \& Agu, N. (2003). Research and statistics in Education and Social Sciences, Methods and Applications, Awka: Nuel publishers \& Academic Press.

Anagbogu, M. A. (2005).Mainstreaming Gender in community development. Paper presented to community leaders in Ekwusigo local government in Anambra State.

Ango, E..P (1991). Marriage Conflicts and Mediations among the Kamatan people of Kaduna state. Unpublished M.Ed. Thesis, University of Jos.

Bala, I.D. (2003). Consequence of early marriage amongst Kaduna women Unpublished PhD Thesis, Ahmadu Bello University Zaria.

Molokwu, J. N (2000) Image of Home Economic in Nigeria. Journal of International federation for Home Economics (IFHC) 6 (2), 38 -45.

Musaazi, J. C (2002). Early marriage Fears, London: Macmillan Publishers Ltd.

Orikpe, E. A. \& Amadi ,U.P.N. (2001). Effective women education in Nigeria: Issues and strategies. In C.A. Nnaka \& M.C. Okeke (eds.). Towards Gender Equality in Nigeria in the 21st Century (99-103). Umunze: Research \&Publication unit.

Oyedepo, F. A (1994) Marriage covenant. Lagos : Dominion publishing house.

UNICEF (2001). Children's and Women's rights in Nigeria: Awake -up call Situation Assessment and Analysis. Abuja: National Planning commission \& UNICEF. 